Akreditasi Ristekdikti,

No: 30/E/KPT/2019 (Sinta 4)

Paradigma,

DOI: https://doi.org/10.31294/p.v23i2.11290

Vol. 23, No. 2 September 2021

P-ISSN 1410-5063, E-ISSN: 2579-3500

\title{
Penerapan Finite State Automata Pada Mesin Tiket Otomatis Bus Damri Di Bandara Internasional Yogyakarta
}

\author{
${ }^{1}$ Universitas Nusa Mandiri \\ e-mail: 14002414@nusamandiri.ac.id \\ ${ }^{2}$ Universitas Nusa Mandiri \\ e-mail: 14002420@nusamandiri.ac.id \\ ${ }^{3}$ Universitas Nusa Mandiri \\ e-mail:14002413@nusamandiri.ac.id \\ ${ }^{4}$ Universitas Nusa Mandiri \\ e-mail: $\underline{14002432 @ \text { nusamandiri.ac.id }}$ \\ ${ }^{5}$ Universitas Nusa Mandiri \\ e-mail:windu@nusamandiri.ac.id
}

Khabib Astoni ${ }^{1}$, Faruq Aziz ${ }^{2}$, Fadillah Said ${ }^{3}$, Dwi Andriyanto ${ }^{4}$ Windu Gata ${ }^{5}$

\begin{abstract}
Abstrak - Sebagai sarana transportasi udara yang vital, Bandara Internasional Yogyakarta membutuhkan sarana alih moda transportasi darat untuk memudahkan penggunanya sampai ke tujuan akhir. Salah satunya adalah Perum Damri yang menyediakan airport shuttle yang melayani ke berbagai tujuan dengan sistem penjualan tiket yang masih dilakukan secara manual dengan waktu pelayanan terbatas dan hanya menerima pembayaran secara tunai sehingga kurang memberikan keleluasaan bagi penggunanya. Dalam penelitian ini, didesain mesin penjualan tiket otomatis berbagai jurusan dengan prinsip kerja menyerupai vending machine yang mengimplementasikan Finite State Automata dengan tujuan meningkatkan kualitas pelayanan kepada pengguna dan memberikan pilihan metode pembayaran yang lebih leluasa. Mesin ini menerima pembayaran tunai dan mengeluarkan cetak tiket dan uang kembalian, atau memotong saldo uang elektronik apabila menggunakan metode pembayaran non tunai secara otomatis. Penerapan rancangan mesin dari penelitian ini diharapkan mampu untuk melayani penjualan tiket secara otomatis dengan pembayaran tunai maupun non tunai tanpa batasan waktu pelayanan, meningkatkan kualitas pelayanan dan memberikan pengalaman baru bagi para penggunanya.
\end{abstract}

Kata Kunci: Finite State Automata, vending machine, mesin tiket otomatis

\begin{abstract}
As a vital air transportation means, Yogyakarta International Airport require land transportation means to facilitate the users to reach their destinations. Perum Damri is one of the airport shuttle provider that serve several destination and sale the tickets manually with limited operational time and accepts cash payment only, that does not provide flexibility for the users. In this study, automatic multi destination ticket machine were designed and resembles the operation of vending machine that implement the Finite State Automata to improve the service quality and offering cash and cashless payment method. This machine accepts cash payment and then issues the ticket along with the cash change, or automatically deducts the balance of the electronic money when using cashless method. The design implementation of this research is expected to be able to serve the ticket sales automatically using cash and cashless method without limitation of operational time, improve the service quality and give the new experiences for the users.
\end{abstract}

Keywords: Finite State Automata, vending machine, automatic ticket machine.

\section{PENDAHULUAN}

Bandara Internasional Yogyakarta (YIA) terletak di Desa Glagah, Kecamatan Temon, Kabupaten Kulon Progo dan menempati wilayah seluas 645,63 Ha. Kapasitas bandara mampu menampung hingga 14 juta orang pertahun. Mulai beroperasi pada tanggal 28
April 2019 dan diharapkan mampu untuk memenuhi kebutuhan akan transportasi udara di Yogyakarta dan sekitarnya (El Hafizah \& Hidayat, 2019).

Demi memudahkan pengguna jasa Bandara dalam melakukan alih moda transportasi ketika melakukan perjalanan, YIA telah didukung oleh moda 
transportasi darat yang cukup lengkap. Beragam jenis transportasi pendukung tersebut antara lain taksi resmi berargo, kereta api bandara, taksi online dan airport shuttle seperti yang telah disediakan oleh Damri yang merupakan penyelenggara pelayanan transportasi darat milik pemerintah.

Sesuai dengan Peraturan Pemerintah Republik Indonesia nomor 31 tahun 1984 tentang Perusahaan Umum Djawatan Angkoetan Motor Repoeblik Indonesia (Perum Damri), Perum Damri merupakan salah satu Perusahaan Umum yang didirikan oleh negara yang diberi wewenang sebagai penyelenggara pemberi layanan jasa angkutan umum, penumpang, dan barang diatas jalan dengan tujuan mengusahakan dan mengembangkan pelayanan angkutan penumpang dan barang di atas jalan dengan kendaraan bermotor untuk menunjang pembangunan negara dan bangsa dalam rangka meningkatkan ketahanan nasional dan mencapai masyarakat adil dan makmur material dan spiritual berdasarkan Pancasila (Rasyid, 2015).

Sampai saat ini, penjualan tiket Bus Damri Bandara masih menggunakan sistem konvensional dimana pembeli datang langsung ke konter penjualan tiket untuk dilayani secara manual dan hanya menerima pembayaran uang tunai saja. Dari permasalahan tersebut, munculah ide untuk mengembangkan simulasi perangkat penjualan tiket onsite yang melayani metode pembayaran tunai ataupun non tunai menggunakan prinsip kerja sebuah vending machine dengan penerapan Finite State Automata.

Teori Bahasa dan otomata mempunyai peran yang fundamental dalam ilmu komputer yang mendasari suatu sistem komputasi (Jamilah \& Nurmansyah, 2018). Otomata merupakan mesin yang dapat menerima input, mengenalinya dan menghasilkan output serta mampu untuk membangkitkan suatu kalimat dengan bahasa tertentu yang dikenali oleh mesin (Said et al., 2020). Teori otomata cenderung berkaitan dengan mesin yang sifatnya abstrak sedangkan teori bahasa lebih dekat dengan komunikasi antara sesama manusia ataupun manusia dengan perangkat mesin sebagai contohnya (Hidayat et al., 2021).

Finite State Automata (FSA) adalah model matematika yang dapat menerima input dan mengeluarkan output yang memiliki state dengan jumlah berhingga dan dapat berpindah dari satu state ke state lainnya (Saputra et al., 2018).

Secara umum, suatu FSA M dapat dinyatakan dalam dalam lima tuple yaitu $\mathrm{M}=\left(\mathrm{Q}, \sum, \delta, \mathrm{S}, \mathrm{F}\right)$ dimana $\mathrm{Q}$ merupakan himpunan state, $\sum$ adalah himpunan simbol masukan, $\delta$ adalah fungsi transisi, $\mathrm{S}$ adalah state awal dan $\mathrm{F}$ adalah state akhir (Irawan et al., 2012)
Dari kemampuannya dalam mengenali, menerima dan menolak yang terdapat pada mesin FSA, terdapat dua jenis FSA yaitu Deterministic Finite Automata (DFA) dan Non-deterministic Finite Automata (NFA) (Saputra et al., 2018).

Sebuah NFA merupakan jenis finite state machine (FSM) dimana salah satu next state tidak sepenuhnya ditentukan oleh current state ataupun input. Himpunan dari possible next states menyatakan bahwa automata dapat berpindah dari state tertentu (qa) ke state yang lain (qb) sebagai tanggapan terhadap suatu input $(\alpha)$. Jenis FSM yang lain, DFA, mempunyai hanya satu start state (q0) dan tepat satu transisi $(\delta)$ untuk setiap anggota himpunan input $\left(\sum\right)$. Dalam NFA, jumlah start state dan transisi untuk setiap anggota himpunan input $\left(\sum\right)$ tidak harus tepat satu (Sahrul, Fitri Karimah, Alzahid Muhazabah, 2018).

Vending Machine adalah sebuah mesin yang dapat melayani jual beli tanpa adanya operator manusia yang menjadi perantara dari transaksi tersebut. Pembeli dapat melakukan transaksi dengan memasukkan sejumlah uang dan memilih sendiri melalui antarmuka pada mesin (Irawan et al., 2012)

Penelitian yang membahas tentang penjualan tiket otomatis menggunakan FSA belum banyak dilakukan. Walaupun demikian, terdapat beberapa penilitian yang dapat dijadikan rujukan karena mempunyai ide dasar dan desain yang tidak jauh berbeda. Rujukan dalam penelitian ini antara lain penelitian yang berjudul Implementasi FSA dalam Proses Pengisian Kartu Rencana Studi oleh Ma'arif (Ma'arif \& Fauziah, 2018). Pada penelitian ini, dilakukan pengembangan sebuah racangan aplikasi pengisian KRS dengan menggunakan FSA. Penelitian selanjutnya adalah Pengembangan Aplikasi Permainan 'Pilah Sampah' Menggunakan Pemodelan FSA oleh Sahrul (Sahrul, Fitri Karimah, Alzahid Muhazabah, 2018) yang membahas tentang penerapan FSA dalam aplikasi permainan pemilahan sampah. Penelitian dengan judul Penerapan FSA pada Aplikasi Simulasi Vending Machine Yoghurt Walagri oleh Suharsih (Suharsih Ririn, 2019) membuat rancangan Vending Machine penjualan minuman yoghurt. Penelitian dengan judul Simulasi Vending Machine Dengan Mengimplementasikan FSA oleh Saputra (Saputra et al., 2018) memberikan gambaran umum mengenai penerapan FSA pada sebuah Vending Machine. Rujukan selanjutnya adalah penelitian dengan judul Desain Vending Machine rokok yang terintegrasi dengan E-KTP oleh Saragih (Gabriel Vangeran Saragih, Anas Faisal, 2020) yang membahas tentang penerapan FSA dalam mesin penjualan rokok otomatis yang terkoneksi dengan basis data E-KTP untuk memvalidasi pembeli berdasarkan umur. Pemodelan Vending Machine 
dengan Metode FSA oleh Wicaksono (Wicaksono et al., 2019) membahas perancangan Vending Machine minuman ringan. Penelitian dengan judul Sistem Pemesanan Tiket Bus Online pada Bandara Udara di Medan Berbasis Android oleh Manurung (Edwin Manurung \& Nasution, 2019) membahas tentang penjualan tiket bus secara online. Referensi terakhir adalah Implementasi FSA dalam Proses Registrasi Workout Plan pada Pusat Kebugaran oleh Rivanie (Rivanie, 2020) yang membuat rancangan aplikasi olah data pengguna pada fitess center.

Pada penelitian ini dilakukan perancangan simulasi untuk memberikan solusi dalam membuat rancang bangun program penjualan tiket yang melayani pembayaran tunai maupun non tunai pada sebuah anjungan tiket otomatis. Tujuan utama penelitian ini adalah menerapkan konsep Finite State Automata ke dalam sebuah aplikasi penjualan tiket secara otomatis yang mampu meningkatkan efisiensi dan memberikan pelayanan terbaik kepada penggunanya.

\section{METODOLOGI PENELITIAN}

Metode yang dilakukan dalam penelitian ini mempunyai beberapa tahapan yang digambarkan pada gambar 1. Langkah pertama yang dilakukan adalah identifikasi masalah, dan telah dibahas pada bab Pendahuluan. Dari langkah pertama dilanjutkan dengan perancangan state diagram yang menjelaskan implementasi FSA sebagai fungsi kontrol pada penjualan tiket kemudian dilanjutkan dengan perancangan sistem. Langkah terakhir adalah mendesain desain tatap muka penjualan tiket otomatis.

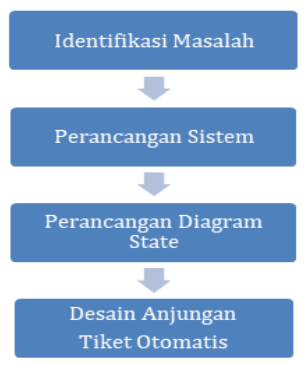

Sumber: (Astoni et al. 2021)

Gambar 1. Metode Penelitian untuk Simulasi

Penjualan Tiket Bus Damri di Yogyakarta International Airport

\section{HASIL DAN PEMBAHASAN}

\section{Identifikasi Masalah}

Penelitian ini bertujuan untuk melakukan otomatisasi dalam proses penjualan tiket dengan masukan uang tunai maupun non tunai dengan menerapkan konsep FSA. Latar belakang penelitian ini telah dijelaskan pada bagian Pendahuluan.

\section{Perancangan Program \\ Perancangan sistem dilakukan dengan menggunakan UML (Unified Modelling} Language) yang terdiri atas Use Case Diagram dan Activity Diagram. Use case diagram menerangkan sistem yang dibuat berdasarkan sudut pandang pengguna (dalam hal ini pembeli tiket), bagaimana interaksinya dengan antar muka sistem seperti yang dijelaskan pada Gambar 2 di bawah.

Penjelasan dari Gambar 2 adalah: pembeli memilih jurusan bus; memilih metode pembayaran; memasukkan uang tunai atau meletakkan kartu uang elektronik dalam scanner; kemudian mengambil tiket dan uang kembalian atau kartu uang elektronik sebagai langkah terakhir.

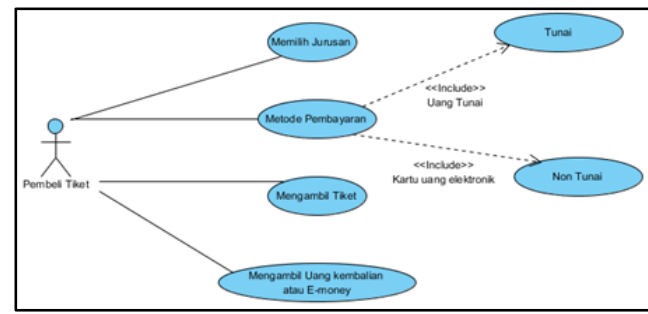

Sumber: (Astoni et al. 2021)

Gambar 2. Use case Diagram penjualan tiket otomatis

Sedangkan Activity Diagram menerangkan urutan suatu rangkaian proses suatu sitem yang sedang dikembangkan, dan dalam hal ini, Activity Diagram menerangkan urutan proses yang harus dilalui oleh pembeli tiket dari awal sampai akhir seperti yang dijelaskan pada gambar 3 di bawah.

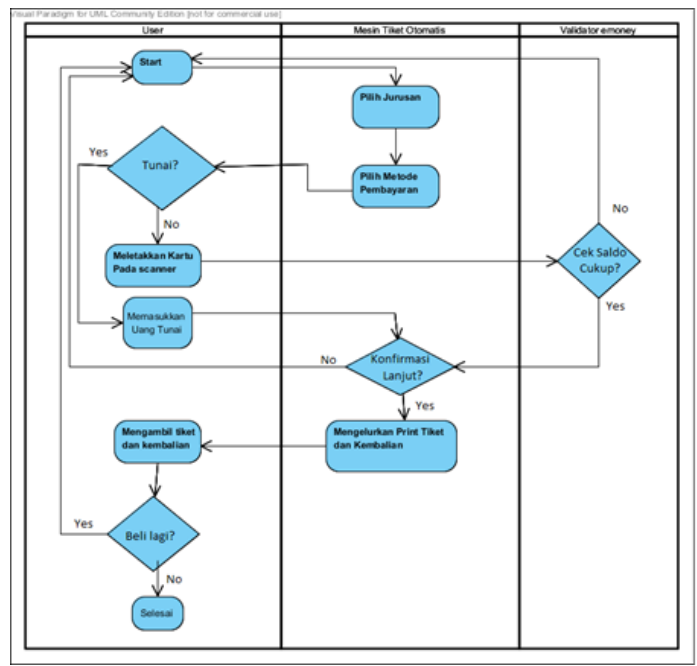

Sumber: (Astoni et al. 2021)

Gambar 3. Activity Diagram Penjualan tiket otomatis 
Penjelasan dari gambar 3 adalah ketika pengguna akan membeli tiket, harus menekan layar dimana saja dan kemudian akan muncul antar muka untuk memilih satu dari empat tujuan yang ditawarkan. Setelah memilih, pengguna harus memilih metode pembayaran apakah tunai ataupun non tunai. Jika memilih pembayaran tunai, pembeli harus memasukkan uang Rupiah pecahan 100 ribuan. Sedangkan jika memilih non tunai, pembeli harus memasukkan kartu uang eletronik pada scanner yang akan memeriksa jumlah saldo pada kartu. Apabila saldo tidak cukup atau kartu tidak dikenali, sistem akan menolak dan proses akan langsung kembali ke awal dengan menampilkan pesan "Saldo uang elektronik Anda tidak mencukupi atau kartu rusak", sedangkan jika saldo cukup, proses akan berlanjut. Langkah terakhir adalah engguna mengambil tiket dan kembalian atau kartu uang elektronik. Satu proses transaksi hanya melayani satu tiket saja, apabila pembeli membutuhkan lebih dari satu harus mengulang dari awal lagi.

\section{Perancangan State diagram}

Setelah berhasil melakukan peracangan sistem, dilakukanlah perancangan awal diagram state yang menggambarkan apa yang harus dilakukan oleh perangkat lunak dengan membuat model perilaku sistem menggunakan obyek matematika seperti set dan urutan. Dari perancangan tersebut akan dapat dibentuk aturan sistematika dari FSA untuk simulasi penjualan tiket.

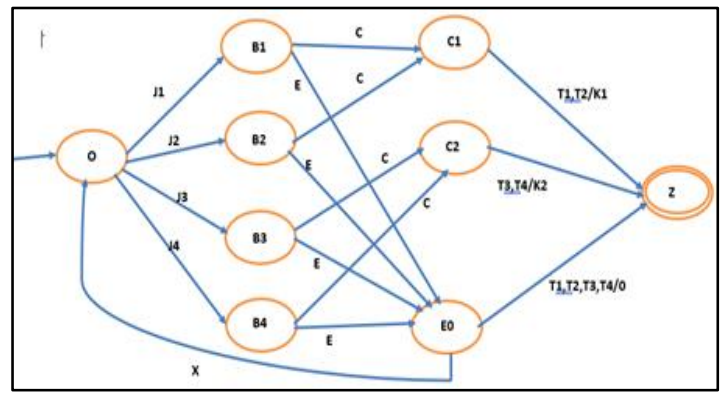

Sumber: (Astoni et al. 2021)

Gambar 4. Diagram State Simulasi Penjualan Tiket Bus Damri di YIA

Konfigurasi mesin dari diagram state di atas adalah sebagai berikut:

$\mathrm{Q}=\{\mathrm{O}, \mathrm{B} 1, \mathrm{~B} 2, \mathrm{~B} 3, \mathrm{~B} 4, \mathrm{C} 1, \mathrm{C} 2, \mathrm{E} 0, \mathrm{Z}\}$

$\sum=\{\mathrm{J} 1, \mathrm{~J} 2, \mathrm{~J} 3, \mathrm{~J} 4, \mathrm{E}, \mathrm{C}\}$

$\mathrm{S}=\{\mathrm{O}\}$

$\Delta=\{\mathrm{T} 1, \mathrm{~T} 2, \mathrm{~T} 3, \mathrm{~T} 4, \mathrm{~K} 1, \mathrm{~K} 2\}$

Tabel 1. Himpunan state

\begin{tabular}{llllll}
\hline $\mathrm{O}$ & Start State & & & & \\
\hline $\mathrm{B} 1$ & Pembelian & Tiket & Bus & Jurusan & 1 \\
\hline
\end{tabular}

\begin{tabular}{|c|c|}
\hline & $\begin{array}{l}\text { (Yogyakarta Kota), harga Rp. } \\
60.000,-\end{array}$ \\
\hline B2 & Pembelian Tiket Bus Jurusan 2 \\
\hline & $\begin{array}{l}\text { (Sleman City Hall), harga Rp. } \\
60.000,-\end{array}$ \\
\hline B3 & $\begin{array}{l}\text { Pembelian Tiket Bus Jurusan } 3 \\
\text { (Borobudur via Menoreh), harga Rp. } \\
70.000,-\end{array}$ \\
\hline B4 & $\begin{array}{l}\text { Pembelian Tiket Bus Jurusan } 4 \\
\text { (Borobudur via Wates), harga Rp. } \\
70.000,-\end{array}$ \\
\hline $\mathrm{C} 1$ & $\begin{array}{l}\text { Pembayaran tunai dengan kembalian } \\
\text { Rp. } 40.000,-\end{array}$ \\
\hline $\mathrm{C} 2$ & $\begin{array}{l}\text { Pembayaran tunai dengan kembalian } \\
\text { Rp. } 30.000,-\end{array}$ \\
\hline E0 & Pembayaran non tunai \\
\hline $\mathrm{Z}$ & Final State \\
\hline
\end{tabular}

Tabel 2. Masukan Program

\begin{tabular}{ll}
\hline $\mathrm{J} 1, \mathrm{~J} 2, \mathrm{~J} 3, \mathrm{~J} 4$ & Jurusan yang dipilih \\
\hline $\mathrm{C}$ & Pembayaran Tunai \\
\hline $\mathrm{E}$ & Pembayaran non tunai \\
\hline $\mathrm{X}$ & Pembayaran non tunai gagal \\
\hline
\end{tabular}

Pada mesin ini terdapat sedikitnya enam input, yaitu tujuan Yogyakarta Kota (Jurusan 1), tujuan Sleman City Hall (Jurusan 2), keduanya dengan harga tiket Rp. 60.000,-, lalu kemudian tujuan Borobudur via Menoreh (Jurusan 3), tujuan Borobudur via Wates (Jurusan 4), dua terakhir dengan harga Rp. 70.000,-, kemudian menerima pembayaran tunai dengan pecahan Rp. 100.000,- dan pembayaran non tunai dengan kartu uang elektronik yang langsung memotong saldo di dalamnya.

Sedangkan outputnya ada enam, yaitu tiket T1 (Tiket Jurusan 1), T2 (Tiket Jurusan), T3 (Tiket Jurusan 3), T4 (Tiket Jurusan 4), K1 (Kembalian Rp. 40.000,-) dan K2 (Kembalian Rp. 30.000,-).

\section{Desain Anjungan Tiket Otomatis}

Setelah melakukan perancangan sistem dan perancangan state diagram, langkah terakhir adalah membuat desain akhir Anjungan tiket otomatis yang meliputi desain fisik dan desain antar muka mesin yang mengakomodasi fungsi dari mesin penjualan otomatis berdasarkan perancangan yang telah dilakukan. Tampilan desain mesin penjualan tiket otomatis diilustrasikan pada gambar 5 di bawah ini. 


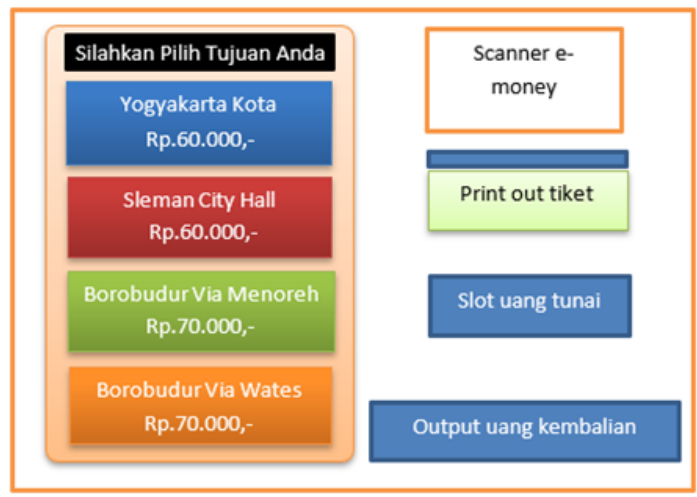

Sumber: (Astoni et al. 2021)

Gambar 5. Desain antarmuka mesin penjualan tiket otomatis

Dari gambar di atas, mesin mempunyai 1) panel layar sentuh untuk memilih tiket, 2) scanner kartu uang elektronik, 3) outlet print out tiket , 4) slot masukan uang tunai dan 5) outlet uang kembalian. Cara kerja dari mesin penjualan tiket otomatis ini adalah sebagai berikut:

a. Calon pembeli tiket menekan layar dimana saja untuk menampilkan daftar tujuan yang tersedia untuk dipilih.

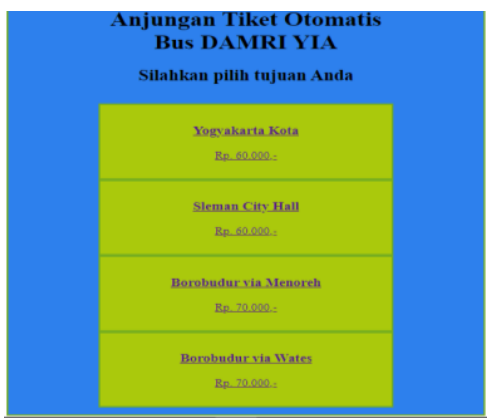

Sumber: (Astoni et al. 2021)

Gambar 6. Desain antarmuka pemilihan tujuan

b. Setelah memilih tujuan, akan muncul dua opsi pembayaran, tunai ataupun non tunai menggunakan kartu uang elektronik.

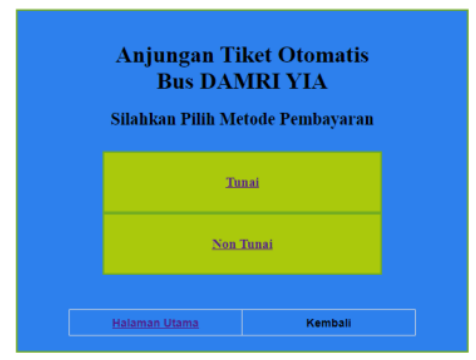

Sumber: (Astoni et al. 2021)

Gambar 7. Desain antarmuka metode pembayaran

c. Selanjutnya adalah proses pembayaran. Apabila memilih pembayaran tunai, pembeli diminta untuk memasukkan uang tunai pecahan seratus ribu rupiah ke dalam slot masukan uang tunai. Namun apabila memilih pembayaran non tunai, pembeli diminta memasukkan kartu uang elektronik ke dalam bilik pemindai yang kemudian akan memeriksa saldo yang tersisa pada kartu. Setelah uang tunai atau kartu uang elektronik masuk, sistem akan melakukan pemindaian uang atau memeriksa saldo yang tersisa pada kartu dan menampilkan konfirmasi untuk melakukan pencetakan tiket.
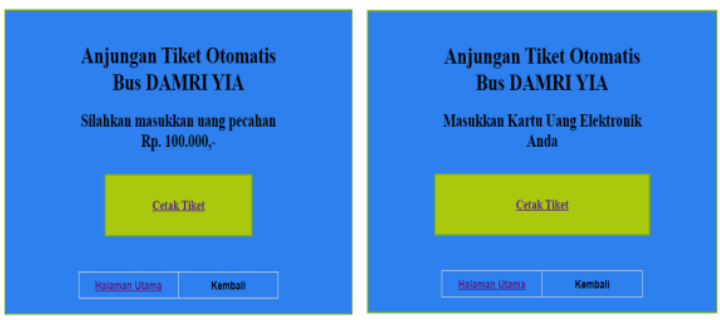

Sumber: (Astoni et al. 2021)

Gambar 8. Desain antarmuka pencetakan tiket

Apabila pembeli melakukan konfirmasi maka tiket akan dicetak dan dapat diambil pada slot print out tiket dan uang kembalian pada outlet uang kembalian atau mengambil kembali kartu uang elektronik pada bilik pemindai yang saldonya telah terpotong.

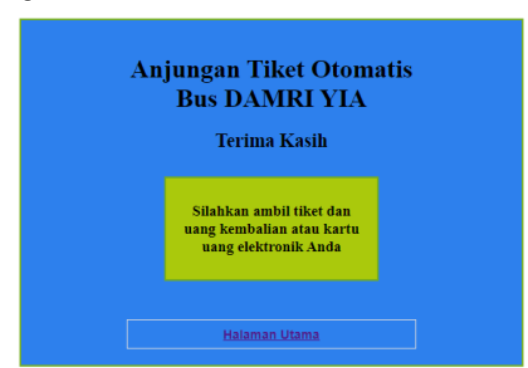

Sumber: (Astoni et al. 2021)

Gambar 9. Desain antarmuka

Namun apabila pengguna memasukkan uang selain pecahan seratus ribu rupiah atau saldo pada uang elektronik tidak mencukupi, maka akan muncul peringatan dan tidak dapat melanjutkan ke proses selanjutnya dan sistem akan kembali ke tampilan awal
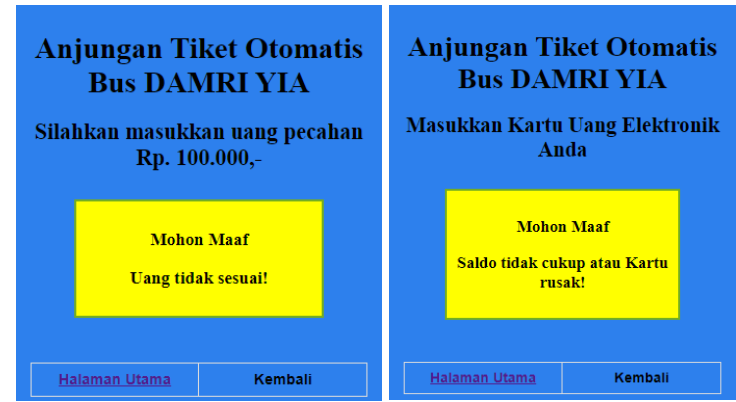

Sumber: (Astoni et al. 2021)

Gambar 10. Desain antarmuka peringatan pembayaran gagal 


\section{KESIMPULAN}

Penerapan dari finite state automata dapat digunakan untuk berbagai aplikasi yang mampu memudahkan dalam berbagai sektor. Salah satu contohnya, FSA dapat dijadikan sebagai logika dasar untuk rancang bangun untuk melakukan perancangan desain penjualan tiket bus otomatis ini dimana FSA akan mengenali simbol masukan yang diberikan, dan selanjutnya akan memproses dan menghasilkan keluaran berdasarkan sesuai dengan masukannya yaitu jurusan dan metode pembayaran yang dipilih serta menghasilkan keluaran berupa cetak tiket dan kembalian uang tunai atau pemotongan saldo uang elektronik. Penerapan dari penelitian ini diharapkan mampu untuk meningkatkan efisiensi dan kualitas pelayanan dari Perum DAMRI kepada masyarakat.

\section{REFERENSI}

Edwin Manurung, J., \& Nasution, R. (2019). SISTEM PEMESANAN TIKET BUS ONLINE PADA BANDARA UDARA DI MEDAN BERBASIS ANDROID. Jurnal TEKINKOM.

El Hafizah, N., \& Hidayat, E. (2019). Analisis Karakteristik Penggunaan Moda Akses Bandara Internasional Yogyakarta. Borneo Engineering: Jurnal Teknik Sipil. https://doi.org/10.35334/be.v3i1.700

Gabriel Vangeran Saragih, Anas Faisal, W. G. (2020). Desain Vending Machine Rokok Dengan Mengimplementasikan Finite State Automata. Desain Vending Machine Rokok Dengan Mengimplementasikan Finite State Automata Terintegrasi Dengan E-KTP.

Hidayat, S., Said, F., Titiani, F., \& Gata, W. (2021). DESAIN KONSEP FINITE STATE AUTOMATA (FSA) PADA SIMULASI VENDING MACHINE (VM) MASAKAN PADANG. Journal of Information System, Informatics and Computing, 5(1), 134-143. https://doi.org/10.52362/JISICOM.V5I1.442

Irawan, J. C., Pakereng, I. M. A., \& Somya, R. (2012). Perancangan dan Implementasi Finite Automata pada Simulasi Vending Machine. D'CARTESIAN. https://doi.org/10.35799/dc.1.1.2012.534

Jamilah, M., \& Nurmansyah, W. (2018). Rancangan Dan Implementasi Aplikasi Alat Bantu Pembelajaran Visualisasi Finite State Automata (Versi Pembuktian Graph ke Tupel). Seminar Nasional Teknologi Dan Bisnis.

Ma'arif, R. A., \& Fauziah, F. (2018). Implementasi Finite State Automata (FSA) dalam Proses Pengisian Kartu Rencana Studi. JOINTECS (Journal of Information Technology and Computer Science). https://doi.org/10.31328/jointecs.v3i3.816

Rasyid, R. B. F. Al. (2015). Kualitas Pelayanan transportasi Publik ( Studi Deskriptif tentang Kualitas Pelayanan Jasa Angkutan Umum Perum Damri Unit Angkutan Bus Khusus Gresik-Bandara Juanda ). Ilmu Administrasi Negara.

Rivanie, T. (2020). Implementasi Finite State Automata dalam Proses Registrasi Workout Plan pada Pusat Kebugaran. MATICS. https://doi.org/10.18860/mat.v12i1.8573

Sahrul, Fitri Karimah, Alzahid Muhazabah, A. D. (2018). Pengembangan Aplikasi Permainan "Pilah Sampah" Menggunakan Pemodelan Finite State Machine. Jurnal Teknologia.

Said, F., Andriyanto, D., Sari, R., \& Gata, W. (2020). Perancangan Validasi Permohonan Narasumber Pada Sistem Informasi Permohonan Narasumber Menggunakan Finite State Automata. Paradigma, 22(2), 189-196. https://doi.org/10.31294/P.V22I2.8157

Saputra, T. I., Fauziah, F., \& Gunaryati, A. (2018). Simulasi Vending Machine Dengan Mengimplementasikan Finite State Automata. JOINTECS (Journal of Information Technology and Computer Science). https://doi.org/10.31328/jointecs.v3i3.819

Suharsih Ririn, F. A. (2019). Penerapan Konsep Finite State Automata ( FSA ) pada Aplikasi Simulasi Vending Machine Yoghurt Walagri. Jurnal Pendidikan Multimedia.

Wicaksono, T. H., Amrizal, F. D., \& Mumtahana, H. A. (2019). Pemodelan Vending Machine dengan Metode FSA ( Finite State Automata ). DoubleClick: Journal of Computer and Information Technology, 2(2), 66-69. http://ejournal.unipma.ac.id/index.php/doubleclick

\section{PROFIL PENULIS}

\section{Khabib Astoni}

Tercatat sebagai mahasiswa Program Magister Ilmu Komputer, Fakultas Ilmu Komputer pada Universitas Nusa Mandiri Jakarta. Saat ini bekerja sebagai koordinator pembelajaran daring di Institut STIAMI Jakarta.

\section{Faruq Aziz}

Tercatat sebagai mahasiswa Program Magister Ilmu Komputer, Fakultas Ilmu Komputer pada Universitas Nusa Mandiri Jakarta.

\section{Fadillah Said}

Tercatat sebagai mahasiswa Program Magister Ilmu Komputer, Fakultas Ilmu Komputer pada Universitas Nusa Mandiri Jakarta. Saat ini bekerja di Badan Penelitian dan Pengembangan Hukum dan Hak Asasi Manusia 


\section{Dwi Andriyanto}

Tercatat sebagai mahasiswa Program Magister Ilmu Komputer, Fakultas Ilmu Komputer pada Universitas Nusa Mandiri Jakarta. Saat ini berkarir sebagai Pranata Komputer Muda di Direktorat Jenderal Pajak

\section{Windu Gata}

Tercatat sebagai dosen tetap pada Program Studi Magister Ilmu Komputer, Fakultas Ilmu Komputer pada Universitas Nusa Mandiri Jakarta 